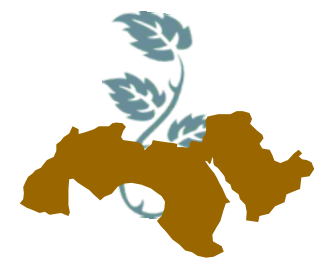

Arab Univ.

J. Agric. Sci., Ain Shams Univ., Cairo, 26(1), 161-169, 2018

\title{
EFFECT OF SOWING MEDIUM AND NITROGEN FERTILIZATION RATES ON PRODUCTION AND GROWTH OF MAHOGANY (SWEITINIA MACROPHYLLA) SEEDLINGS
}

\author{
[11] \\ Mona S.M. Ahmed ${ }^{1}$; N.A. Abdel-Ghany ${ }^{2}$; U.A. El-Behairy ${ }^{2}$ and Samah I. Nasr ${ }^{3}$ \\ 1- Central Administration of Afforestation and Environmental, Ministry of Agric., Giza, Egypt \\ 2- Horticulture Dept., Fac. of Agric., Ain Shames Univ., Cairo, Egypt \\ 3- Higher Institute Agric. Co-operation, Cairo, Egypt
}

Keywords: Mahogany, Sowing, Medium, Swietenia, Macrophylla, Fertilization, Seedlings

\section{ABSTRACT}

This study was carried out at the nursery of Horticulture Department, Faculty of Agriculture, Ain Shames University during two seasons of 2015 and 2016 to study the effect of sowing medium and fertilization rates on vegetative growth and chemical composition of Swietenia macrophylla seedlings. Three different sowing media were used i.e., $S M_{1}=$ perlite: peat moss: compost (1:1:1), $\mathrm{SM}_{2}=$ perlite: peat moss: compost $(1: 2: 1)$ and $\mathrm{SM}_{3}=$ perlite: peat moss: compost $(1: 1: 2)$ $(\mathrm{v} / \mathrm{v})$. Also, four fertilization rates were used as follow: without fertilizer (control), 5, 10 and $15 \mathrm{~g}$ /plant of hydrocomplex fertilizer. The following data were recorded, stem length $(\mathrm{cm})$, stem diameter $(\mathrm{cm})$, number of leaves / plant, leaf area $\left(\mathrm{cm}^{2}\right)$ and total fresh and dry biomass (gm). Moreover, chlorophyll a \& b leaves contents (mg/g FW.), total carbohydrate content (mg/g DW), nitrogen, phosphorus and potassium content in leaves (\% D.W.) were determined. Regarding the effect of sowing medium, the obtained results showed that, using sowing medium which content the highest percentage of compost (1:1:2) significantly increased stem length, stem diameter, number of leaves/ plant, leaf area, total fresh and dry biomass, total carbohydrate content and potassium leaves content in comparison the other growing medium while, the differences were insignificant in chlorophyll a \& b, nitrogen and phosphorus leaves content. Concerning the effect of fertilization rates, using fertilization at the rate of $15 \mathrm{~g} /$ plant caused significantly increased stem length, stem diameter, number of leaves / plant, leaf area, total fresh and dry biomass, chlorophyll a \& b content, total carbohydrate content, nitrogen, phosphorus and potassium leaves content in comparison the other fertilization rates with the exception of leaf area, chlorophyll a, phosphorus and potassium leaves content at the rate of $10 \mathrm{~g} / \mathrm{plant}$ in the second seasons only. As for the interaction between sowing medium and fertilization rates, In general, application of growing medium which contain thehigh ratio of compost (1:1:2) was superior in all tested characteristics followed by which contain the high ratio of peat moss (1:2:1)at $15 \mathrm{gm}$ fertilizationas compared to the other treatments.

\section{INTRODUCTION}

Mahogany (Swietenia macrophylla) belongs to Family Meliaceae, is one of the most important timber species in world trade. It is principally used for making furniture and interior fittings and has been an important component in construction and ship building. Its high economic value has resulted in overexploitation across its natural range and this, coupled with high deforestation rates, has led to the species becoming the focus of increasing concern. Swietenia macrophylla may be tolerant to a wide range of environmental conditions. Also, it is tolerant of a wide range of soil conditions but grows best in alluvial, volcanic, heavy clays and lateritic soils derived from a wide range of parent materials. (Mayhew and Newton, 1998).

A good quality growing medium can improve morphological characteristics of seedlings and produce higher quality seedlings in a shorter amount of time. The quality of nursery seedlings is influenced by potting media (Agbo and Omaliko 2006). The soil media have several important functions in relation to plant growth. They provide an- 
chorage for the plant's roots; air spaces to allow respiration; and it acts as a plant support, serves as a source of water and essential plant nutrients and permits the diffusion of oxygen to roots to satisfy these basic plant requirements (Bhardwaj, 2014). Moreover, Vidyasagaran and Kumar (2017) indicated that, using the following components viz. - Soil: Sand: cow dung (1:1:1); Soil: Municipal waste $(1: 1)$ and Soil: Tea waste: Sand $(1: 1: 1)$ were the best combination of potting media to manifest maximum performance of various growths attributes for Tectona grandis, Swietenia macrophylla and Ailanthus triphysa respectively.

Fertilization enhance seedlings growth and development during the nursery growing period and quality of seedlings can be improved by managing type, amount, and time of fertilization Improving the fertility of nursery soils is essential to guarantee the production of high quality seedlings for nursery establishment. Jayasinghe and Ranasinghe (2009) study the effect of 16 fertilizer combinations on 6 months old of Swietenia macrophylla seedlings. Plantations which are poor in soil nutrients gave a higher response to the fertilization. As the growth response to fertilizer applications is a long term process it is recommended that long term field experiments should be established and maintained. Moreover, Hamdan (2012) showed that, the dosages of NPK fertilizer caused significant different on the variation of height, diameter, total dry weight and seedling quality index of mahogany Swietenia macrophylla seedlings at nursery. ElKkady and Suloma (2013) compared various types of fertilization sources of Khaya and Mahogany Seedlings. NPK treatment was significantly superior to other treatments in improving overall studied seedling metrics, (plant height, stem diameter, compound leaves number/plant, root number/ plant.

The main objective of this study was to investigate the effect of different sowing medium, different fertilization rates and the interaction between them on vegetative growth and chemical composition of Swietenia macrophylla seedlings in order to increase its quantity and improve its quality.

\section{MATERIALS AND METHODS}

This study was carried out at the nursery of Horticulture Department, Faculty of Agriculture, Ain Shames University during two successive seasons of, 2015 and 2016to study the effect of sowing medium and fertilization rates on vegetative growth and chemical composition of Swietenia macrophylla seedlings.

Sex month old seedlings were planted on $15^{\text {th }}$ March in both seasons in plastic pots $25 \mathrm{~cm}$ diameter (one plant/pot, the average height of seedlings were $15 \mathrm{~cm}$, each pot filed with three different soil media according to treatments i.e. , $\mathbf{S M}_{\mathbf{1}}=$ perlite : peat moss: compost added percentage 1:1:1, $\mathbf{S M}_{\mathbf{2}}=$ perlite: peat moss: compost added percentage $1: 2: 1$ and $\mathbf{S M}_{\mathbf{3}}=$ perlite : peat moss: compost added percentage at 1:1:2 (v/v). Commercially fertilizer used through this experimental work was hydrocomplex NPK (12:11:18) in addition some trace elements, $2.5 \% \mathrm{Ca}, 1.6 \% \mathrm{Mg}, 0.015 \% \mathrm{~B}$, $0.2 \% \mathrm{Fe}, 0.02 \% \mathrm{Mn}, 0.02 \% \mathrm{Zn}$ and $0.025 \% \mathrm{Cd}$, English produced. Fertilization rates were added in three equal doses, first dose at planting by mixing with sowing medium, second and third dose were added after 2 and 4 months from transplanting by adding surrounded the base of seedlings. The fertilizer rates were: $\mathbf{F} 1=$ without fertilizer (control), $\mathbf{F}_{2}=5 \mathrm{~g} /$ plant, $\mathbf{F}_{3}=10 \mathrm{~g} /$ plant and $\mathbf{F}_{\mathbf{4}}=15 \mathrm{~g} /$ plant. At the end of both growing seasons at the $15^{\text {th }}$ September 2015 and 2016, after sex month from transplanting, the following data were recorded: Stem length $(\mathrm{cm})$, Stem diameter $(\mathrm{cm})$, Number of leaves/ plant, Total fresh biomass ( $\mathrm{gm}$ ), Total dry biomass $(\mathrm{gm})$, Leaf area $\left(\mathrm{cm}^{2}\right)$ were measured according to Vivekanandan et al (1972) Leaves samples of each seedling/replicate were taken and oven dried at $70^{\circ} \mathrm{C}$ till constant weight and then ground and stored for analysis. Also, plant sample were wet digested according to Chapman and Pratt (1961) The following chemical analysis were determined: Chlorophyll $a \& b$ contents (mg/g FW) were determined according to Saric et al (1967), Total carbohydrates (mg/g DW) were determined according to Herbert et al (1971) Nitrogen content in leaves (\%D.W.) were determined by the modified micro-Kjeldahl method as described by Cottenie et al (1982) Phosphorus content in leaves (\%DW.) were estimated using ammonium molybdate method according to Snell and Snell (1949) Potassium content in leaves (\%D.W.) were measured in the digested solutionby flam photometer according to Chapman and Pratt (1961).

The layout of the experiment was a complete randomized design, the experiment included 12 treatments ( 4 fertilization rates $\times 3$ sowing medium) each treatment included 3 replicates; each replicate consisted of three pots. The obtained results were subjected to statistical analysis of variance (ANOVA) according to the method described by 
Snedecor and Cochran (1982) using MSTAT program. Least significant ranges (LSR) were used to compare between means of treatments according to Duncan (1955).

\section{RESULTS AND DISCUSSION}

\section{Vegetative growth characteristics}

\section{a- Stem length and Stem diameter (cm)}

It is obvious from data in Table (1) that, application the fertilization rate at $(15 \mathrm{~g} /$ plant) were produced the tallest plants $(98.06$ and $104.43 \mathrm{~cm}$ ) and the thickest stems $(2.25,2.12 \mathrm{~cm})$ in comparison of the other fertilization treatments in both seasons, respectively. Hamdan (2012) showed that, the dosages of NPK fertilizer caused significant different on the variation of height and diameter of Swietenia macrophylla seedlings. Concern- ing the effect of sowing media, S.M. (1:1:2) produced the highest values of stem length $(89.08$ and $91.75 \mathrm{~cm}$ ) and stem diameter $(2.06,1.88 \mathrm{~cm})$, respectively in the two seasons of study as compared to the other treatments. Sardoei and Rahbarian (2014) on Ficus benjamina, Padanus sanderi and Rosmarinus officinalis plants showed that, the mean media $50 \%$ peat moss $+25 \%$ sand $+25 \%$ perlite had the highest average stem length. The same data cleared that, using both of fertilization at the rate of (15 g/plant) and sowing medium at percentage of (1:1:2) caused significantly increased in stem length and stem diameter in both seasons as compared to the other treatments. AlMenaie et al (2012) on Cassia nodosa and Cassia fistula seedlings showed that, both the species of Cassia exhibited maximum plant height when $\mathrm{N}$ : $\mathrm{P}$ : $\mathrm{K}$ was applied at $1 \mathrm{~g} / \mathrm{l}$ in a growing medium comprising of sand: peat moss: humus $(1: 1: 1 \mathrm{v} / \mathrm{v})$ compared to other fertilizer levels.

Table 1. Effect of Sowing medium and fertilization rates on stem length and stem diameter of Swietenia macrophylla seedlings during 2015 and 2016 seasons .

\begin{tabular}{|c|c|c|c|c|c|c|c|c|}
\hline \multirow{3}{*}{ Treatmentes } & \multicolumn{8}{|c|}{2015 Season } \\
\hline & \multicolumn{3}{|c|}{ Stem length (cm) } & \multirow{2}{*}{ Mean } & \multicolumn{3}{|c|}{ Stem diameter $(\mathrm{cm})$} & \multirow{2}{*}{ Mean } \\
\hline & S.M.1 & S.M.2 & S.M. .3 & & S.M.1 & S.M.2 & S.M.M & \\
\hline $\mathbf{F}_{1}$ & $69.50 \mathrm{~h}$ & $70.90 \mathrm{gh}$ & $72.40 \mathrm{gh}$ & $70.93 \mathrm{D}$ & $1.65 f$ & $1.69 \mathrm{f}$ & $1.72 \mathrm{f}$ & $1.69 \mathrm{D}$ \\
\hline$F_{2}$ & $76.70 \mathrm{fg}$ & 81.60 ef & $87.30 \mathrm{~d}$ & $81.87 \mathrm{C}$ & $1.88 \mathrm{de}$ & 1.82 ef & $1.95 \mathrm{de}$ & $1.88 \mathrm{C}$ \\
\hline$F_{3}$ & $86.60 \mathrm{de}$ & 90.70 ed & $95.90 \mathrm{bc}$ & $91.07 \mathrm{~B}$ & $2.00 \mathrm{~cd}$ & $2.17 \mathrm{bc}$ & $2.22 a b$ & $2.13 \mathrm{~B}$ \\
\hline$F_{4}$ & $93.50 \mathrm{c}$ & $100.0 \mathrm{ab}$ & $100.70 \mathrm{a}$ & $98.06 \mathrm{~A}$ & $2.11 \mathrm{c}$ & $2.28 a b$ & $2.36 \mathrm{a}$ & $2.25 \mathrm{~A}$ \\
\hline Mean & $81.58 \mathrm{C}$ & $85.80 \mathrm{~B}$ & $89.08 \mathrm{~A}$ & & $1.91 \mathrm{~B}$ & $1.99 \mathrm{AB}$ & $2.06 \mathrm{~A}$ & \\
\hline \multirow{2}{*}{ Treatmentes } & \multicolumn{8}{|c|}{2016 Season } \\
\hline & S.M.1 & S.M.2 & S.M. .3 & Mean & S.M.1 & S.M.2 & S.M.3 & Mean \\
\hline$F_{1}$ & $66.30 \mathrm{~g}$ & $75.20 \mathrm{fg}$ & $73.50 \mathrm{fg}$ & $71.67 \mathrm{D}$ & $1.50 \mathrm{f}$ & $1.52 \mathrm{f}$ & $1.47 f$ & $1.50 \mathrm{D}$ \\
\hline$F_{2}$ & 80.70 ef & 80.90 ef & $84.30 \mathrm{de}$ & $81.97 \mathrm{C}$ & $1.62 \mathrm{ef}$ & $1.67 \mathrm{e}$ & $1.74 \mathrm{de}$ & $1.68 \mathrm{C}$ \\
\hline$F_{3}$ & $90.70 \mathrm{~cd}$ & $95.20 \mathrm{c}$ & $96.80 \mathrm{bc}$ & $94.23 \mathrm{~B}$ & $1.84 \mathrm{~cd}$ & $1.97 \mathrm{bc}$ & $2.03 \mathrm{~b}$ & $1.95 \mathrm{~B}$ \\
\hline$F_{4}$ & $97.40 \mathrm{bc}$ & $103.50 \mathrm{~b}$ & $112.40 \mathrm{a}$ & $104.43 \mathrm{~A}$ & $1.95 \mathrm{bc}$ & $2.12 a b$ & $2.28 \mathrm{a}$ & $2.12 \mathrm{~A}$ \\
\hline Mean & 83.78 B & $88.70 \mathrm{~A}$ & $91.75 \mathrm{~A}$ & & $1.73 \mathrm{~B}$ & $1.82 \mathrm{AB}$ & $1.88 \mathrm{~A}$ & \\
\hline
\end{tabular}

S.M.1 $=$ Perlite : Peat moss : Compost added percentage at 1:1:1

S.M. $._{2}=$ Perlite $:$ Peat moss $:$ Compost added percentage at $1: 2: 1$

S.M. $\mathbf{M}_{3}=$ Perlite $:$ Peat moss $:$ Compost added percentage at 1:1:2

$\mathbf{F}_{4}=$ added hydrocomplex at $15 \mathrm{~g}$ per plant

Values followed by the same letter (s) are not significantly different at $5 \%$ level
$\mathbf{F}_{1}=$ without adding hydrocomplex

$\mathbf{F}_{2}=$ added hydrocomplex at $5 \mathrm{~g}$ per plant

$\mathbf{F}_{3}=$ added hydrocomplex at $10 \mathrm{~g}$ per plant 


\section{b- Number of leaves / plantand Leaf area $\left(\mathrm{cm}^{2}\right)$}

It is evident from data presented in Table (2) that, using fertilization rate at (15 g/plant) significantly increased number of leaves /plant (16.90 and 16.30) and leaf area (119.70 and $\left.105.90 \mathrm{~cm}^{2}\right)$ in comparison with the other treatments in both seasons, respectively. Watfa (2009) showed that, NPK fertilization treatments significantly increased the number of leaves of Aleppo pine seedlings. Also, the sowing medium which contains the high ratio of compost (1:1:2) produced the highest values of number of leaves /plant (14.40 and 13.90) and $\left(102.70\right.$ and $\left.92.70 \mathrm{~cm}^{2}\right)$ for leaf area in the two seasons of study, respectively. EL-Quasni et al (2014) showed that, the media of peat moss +sand+ perlite gave the highest values of number of leaves and leaf area of Magnolia grandiflora seedlings. As regard the interaction between the two factor of study, increasing fertilization rates up to (15 g/plant) caused significant increase in both of number of leaves and leaf area in all sowing medium in both seasons of study. Al-Menaie et al (2012) reported that, application of $\mathrm{N}: \mathrm{P}: \mathrm{K}$ at $1 \mathrm{~g} / \mathrm{l}$ in a growing medium comprising of sand: peat moss: humus $(1: 1: 1 \mathrm{v} / \mathrm{v})$ on Cassia nodosa and Cassia fistula seedlings exhibited maximum number of leaves.

Table 2. Effect of Sowing medium and fertilization rates on Number of leaves / plant and leafe area of Swietenia macrophylla seedlings during 2015 and 2016 seasons .

\begin{tabular}{|c|c|c|c|c|c|c|c|c|}
\hline \multirow{3}{*}{ Treatments } & \multicolumn{8}{|c|}{2015 Season } \\
\hline & \multicolumn{3}{|c|}{ Number of leaves / plant } & \multirow{2}{*}{ Mean } & \multicolumn{3}{|c|}{ leafe area $\left(\mathrm{cm}^{2}\right)$} & \multirow{2}{*}{ Mean } \\
\hline & S.M.1 & S.M.2 & S.M.3 & & S.M.1 & S.M.2 & S.M.3 & \\
\hline$F_{1}$ & $9.8 \mathrm{~g}$ & $10.0 \mathrm{~g}$ & $10.3 \mathrm{~g}$ & $10.0 \mathrm{D}$ & $67.5 \mathrm{~h}$ & $74.1 \mathrm{~g}$ & $72.1 \mathrm{gh}$ & $71.2 \mathrm{D}$ \\
\hline$F_{2}$ & $12.0 \mathrm{f}$ & $12.0 \mathrm{f}$ & $13.2 \mathrm{e}$ & $12.4 \mathrm{C}$ & $88.9 \mathrm{f}$ & $85.4 f$ & $95.1 \mathrm{e}$ & $89.8 \mathrm{C}$ \\
\hline$F_{3}$ & $14.9 \mathrm{~d}$ & $15.7 \mathrm{c}$ & $16.5 \mathrm{~b}$ & $15.7 \mathrm{~B}$ & $111.7 \mathrm{~cd}$ & $108.7 \mathrm{~d}$ & $117.9 \mathrm{~b}$ & $112.8 \mathrm{~B}$ \\
\hline $\mathbf{F}_{4}$ & $16.2 \mathrm{bc}$ & $16.9 a b$ & $17.5 \mathrm{a}$ & $16.9 \mathrm{~A}$ & $115.0 \mathrm{bc}$ & $118.6 \mathrm{~b}$ & $125.6 \mathrm{a}$ & 119.7A \\
\hline Mean & $13.2 \mathrm{~B}$ & $13.7 \mathrm{~B}$ & $14.4 \mathrm{~A}$ & & $95.8 \mathrm{C}$ & $96.7 \mathrm{~B}$ & $102.7 \mathrm{~A}$ & \\
\hline \multirow{2}{*}{ Treatmentes } & \multicolumn{8}{|c|}{2016 Season } \\
\hline & S.M.1 & S.M.2 & S.M.3 & Mean & S.M.1 & S.M.2 & S.M.3 & Mean \\
\hline$F_{1}$ & $9.0 \mathrm{f}$ & $9.3 \mathrm{f}$ & $9.8 \mathrm{f}$ & $9.4 \mathrm{D}$ & $62.1 \mathrm{e}$ & $62.2 \mathrm{e}$ & $66.3 \mathrm{e}$ & $66.3 \mathrm{C}$ \\
\hline$F_{2}$ & $11.0 \mathrm{e}$ & $11.4 \mathrm{e}$ & $12.7 \mathrm{~d}$ & $11.7 \mathrm{C}$ & $75.9 d$ & $75.2 d$ & $86.1 \mathrm{c}$ & $79.1 \mathrm{~B}$ \\
\hline$F_{3}$ & $14.2 \mathrm{c}$ & $15.1 \mathrm{~b}$ & $16.4 \mathrm{a}$ & $15.2 \mathrm{~B}$ & $97.1 \mathrm{~b}$ & $101.7 b$ & $110.7 \mathrm{a}$ & $103.2 \mathrm{~A}$ \\
\hline$F_{4}$ & $15.6 \mathrm{a}$ & $16.3 \mathrm{a}$ & $16.7 \mathrm{a}$ & $16.3 \mathrm{~A}$ & $98.7 \mathrm{~b}$ & $110.4 \mathrm{a}$ & $108.5 \mathrm{a}$ & $105.9 \mathrm{~A}$ \\
\hline Mean & $12.5 \mathrm{~B}$ & $13.0 \mathrm{~B}$ & $13.9 \mathrm{~A}$ & & $83.5 \mathrm{C}$ & $87.4 \mathrm{~B}$ & $92.9 \quad \mathrm{~A}$ & \\
\hline
\end{tabular}

\section{c- Total fresh and dry biomass (gm)}

It is obvious from data presented in Table (3) that, the highest values of total fresh biomass (212.0 and $209.10 \mathrm{gm})$ and (81.20 and $81.10 \mathrm{gm})$ for total dry biomass were produced by application of fertilization rates at ( $15 \mathrm{~g} /$ plant) in comparison the other treatments in both seasons, respectively. Hamdan (2012) showed that, the dosages of NPK fertilizer caused significant different on the variation of total dry weight of Swietenia macrophylla seedlings. concerning the effect of sowing medium, the same data revealed that, the highest values of total fresh biomass (181.20 and $183.20 \mathrm{gm}$ ) and $(69.8$ and $71.30 \mathrm{gm}$ ) for total dry biomass in both seasons, respectively were produced by plants grown in medium which contain the highest ratio of compost $(1: 1: 2)$. Uğur et al (2010) indicat- ed that, the use of peat + perlite led to increased plant growth and quality of fig nursery trees grown in hight-tunnel. The same data showed that, increasing the ratio of compost or peat moss in sowing medium (1:1:2 and $1: 2: 1)$ at the rate of (15 $\mathrm{g} /$ plant) significantly increased both of total fresh and dry biomass as compared to the other treatments in the two seasons of study.

The positive effect on vegetative growth characteristics may be due to the role of NPK in plant growth which plays an important role in plant development because NPK have important role in different physiological processes of metabolites that enhance cell division and elongation in cambium zone (Zhang et al 2010). In addition that, compost is provides plant nutrients that are released throughout the growing season, improves soil structure (Ching et al 2011). 

Mahogany (Sweitinia macrophylla) seedlings

Table 3. Effect of Sowing medium and fertilization rates on total fresh and dry biomass of Swietenia macrophylla seedlings during 2015 and 2016 seasons.

\begin{tabular}{|c|c|c|c|c|c|c|c|c|}
\hline \multirow{3}{*}{ Treatments } & \multicolumn{8}{|c|}{2015 Season } \\
\hline & \multicolumn{3}{|c|}{ Total fresh biomass (gm) } & \multirow{2}{*}{ Mean } & \multicolumn{3}{|c|}{ Total dry biomass (gm) } & \multirow{2}{*}{ Mean } \\
\hline & S.M.1 & S.M.2 & S.M.3 & & S.M.1 & S.M.2 & S.M.3 & \\
\hline $\mathbf{F}_{1}$ & $124.6 \mathrm{~h}$ & $130.4 \mathrm{~h}$ & $131.7 \mathrm{~h}$ & $127.9 \mathrm{D}$ & $46.0 \mathrm{~g}$ & $48.3 \mathrm{~g}$ & $48.8 \mathrm{~g}$ & $48.7 \mathrm{D}$ \\
\hline$F_{2}$ & $157.5 \mathrm{~g}$ & $155.3 \mathrm{~g}$ & $168.0 \mathrm{f}$ & $158.2 \mathrm{C}$ & $59.3 f$ & $58.8 \mathrm{f}$ & $64.5 \mathrm{e}$ & $60.8 \mathrm{C}$ \\
\hline $\mathbf{F}_{3}$ & $181.0 \mathrm{e}$ & $196.6 \mathrm{~d}$ & $207.3 \mathrm{bc}$ & 194.3 B & $69.1 \mathrm{~d}$ & $73.7 \mathrm{c}$ & $77.3 \mathrm{~b}$ & $69.7 \mathrm{~B}$ \\
\hline $\mathbf{F}_{4}$ & $198.7 \mathrm{~cd}$ & $213.6 \mathrm{~b}$ & $224.7 \mathrm{a}$ & $212.0 \mathrm{~A}$ & $76.3 \mathrm{bc}$ & $80.6 \mathrm{a}$ & $83.7 \mathrm{a}$ & $81.2 \mathrm{~A}$ \\
\hline Mean & $165.9 \mathrm{C}$ & $172.2 \mathrm{~B}$ & $181.2 \mathrm{~A}$ & & $60.1 \mathrm{C}$ & $65.4 \mathrm{~B}$ & $69.8 \mathrm{~A}$ & \\
\hline \multirow{2}{*}{ Treatmentes } & \multicolumn{8}{|c|}{2016 Season } \\
\hline & S.M.1 & S.M.2 & S.M. & Mean & S.M.1 & S.M.2 & S.M.3 & Mean \\
\hline $\mathbf{F}_{1}$ & $117.8 \mathrm{f}$ & $123.0 \mathrm{f}$ & $125.7 \mathrm{f}$ & $120.2 \mathrm{D}$ & $44.5 \mathrm{~g}$ & $47.3 \mathrm{f}$ & $47.7 \mathrm{f}$ & $46.8 \mathrm{D}$ \\
\hline$F_{2}$ & 140.2 e & $145.2 \mathrm{e}$ & $147.3 \mathrm{e}$ & $160.9 \mathrm{C}$ & $54.9 \mathrm{e}$ & $56.5 \mathrm{de}$ & $57.1 \mathrm{~d}$ & $61.8 \mathrm{C}$ \\
\hline$F_{3}$ & $179.5 d$ & $194.2 \mathrm{c}$ & $206.8 \mathrm{ab}$ & $192.0 \mathrm{~B}$ & $72.3 \mathrm{c}$ & $71.3 \mathrm{c}$ & $80.0 \mathrm{ab}$ & $72.8 \mathrm{~B}$ \\
\hline$F_{4}$ & $198.9 \mathrm{c}$ & $207.3 \mathrm{ab}$ & $213.3 \mathrm{a}$ & $209.1 \mathrm{~A}$ & $79.3 \mathrm{~b}$ & $82.6 \mathrm{a}$ & $82.3 \mathrm{a}$ & $81.1 \mathrm{~A}$ \\
\hline Mean & $160.1 \mathrm{C}$ & $168.4 \mathrm{~B}$ & $183.2 \mathrm{~A}$ & & $61.5 \mathrm{C}$ & $64.2 \mathrm{~B}$ & $71.3 \quad \mathrm{~A}$ & \\
\hline
\end{tabular}

Chemical composition

\section{a- Chlorophyll a \& b leaves content $(\mathrm{mg} / \mathrm{g}$ FW)}

Data presented in Table (4) showed that, application of fertilization rate at (15 g/plant) significantly increased chlorophyll a \& b leaves content $(0.940$ and $0.612 \mathrm{mg} / \mathrm{g} \mathrm{FW})$ in the first season and $(0.898$ and $0.600 \mathrm{mg} / \mathrm{g} \mathrm{FW})$ in the second season as compared the other tested rates in both seasons with the exception of the rate of $(10 \mathrm{gm} /$ seedling) in second seasons only. Habib (2012) reported that, using NPK at the highest rate $(4 \mathrm{gm})$ resulted in the highest content of chlorophyll $a \& b$ as compared to other fertilization rates on Caryota mitis seedlings. On other hand, the differences among all tested sowing medium were not significant on chlorophyll a \& b content. Similar results have been found by El-Khateeb et al (2006) on Ficus alii. As for the interaction the highest values of chlorophyll a \& b content were produced by using the rate of (15 g/plant) in all tested sowing medium in comparison the other treatments in both seasons of study. The increase in total chlorophyll could be attributed to the important role of NPK nutrients in photosynthesis, energy compounds and other physiological processes, which reflected directly on increasing the content of chlorophyll a \& b (Devlin, 1972).

Table 4. Effect of Sowing medium and fertilization rates on chlorophyll a \& b content of Swietenia macrophylla seedlings during 2015 and 2016 seasons.

\begin{tabular}{|c|c|c|c|c|c|c|c|c|}
\hline \multirow{3}{*}{ Treatments } & \multicolumn{8}{|c|}{2015 Season } \\
\hline & \multicolumn{3}{|c|}{$\begin{array}{c}\text { chlorophyll A content (mg/g } \\
\text { FW) }\end{array}$} & \multirow[t]{2}{*}{ Mean } & \multicolumn{3}{|c|}{$\begin{array}{c}\text { chlorophyll B content }(\mathrm{mg} / \mathrm{g} \\
\text { FW) }\end{array}$} & \multirow[t]{2}{*}{ Mean } \\
\hline & S.M.1 & S.M.2 & S.M. & & S.M.1 & S.M.2 & S.M.3 & \\
\hline$F_{1}$ & $0.679 \mathrm{e}$ & $0.713 \mathrm{de}$ & $0.749 d$ & $0.713 \mathrm{C}$ & $0.483 \mathrm{de}$ & $0.467 \mathrm{de}$ & $0.452 \mathrm{e}$ & $0.470 \mathrm{C}$ \\
\hline$F_{2}$ & $0.726 \mathrm{de}$ & $0.753 d$ & $0.765 d$ & $0.748 \mathrm{C}$ & 0.492 de & $0.478 \mathrm{de}$ & $0.496 \mathrm{de}$ & $0.489 \mathrm{~B}$ \\
\hline$F_{3}$ & $0.851 \mathrm{bc}$ & $0.866 \mathrm{bc}$ & $0.847 \mathrm{c}$ & $0.855 \mathrm{~B}$ & $0.526 \mathrm{~cd}$ & $0.542 \mathrm{bc}$ & $0.551 \mathrm{bc}$ & $0.539 \mathrm{~B}$ \\
\hline $\mathbf{F}_{4}$ & $0.936 \mathrm{a}$ & $0.920 a b$ & $0.965 \mathrm{a}$ & $0.940 \mathrm{~A}$ & $0.611 \mathrm{a}$ & $0.594 \mathrm{ab}$ & $0.632 \mathrm{a}$ & $0.612 \mathrm{~A}$ \\
\hline Mean & $0.798 \mathrm{~A}$ & $0.813 \mathrm{~A}$ & $0.832 \mathrm{~A}$ & & $0.528 \mathrm{~A}$ & $0.523 \mathrm{~A}$ & $0.533 \mathrm{~A}$ & \\
\hline \multirow{2}{*}{ Treatmentes } & \multicolumn{8}{|c|}{2016 Season } \\
\hline & S.M.1 & S.M.2 & S.M. .3 & Mean & S.M.1 & S.M. .2 & S.M.3 & Mean \\
\hline$F_{1}$ & $0.667 \mathrm{e}$ & $0.708 \mathrm{de}$ & $0.724 \mathrm{de}$ & $0.699 \mathrm{~B}$ & $0.407 d$ & $0.421 d$ & $0.411 d$ & $0.413 C$ \\
\hline$F_{2}$ & $0.725 \mathrm{de}$ & $0.767 \mathrm{~cd}$ & $0.711 \mathrm{de}$ & $0.734 \mathrm{~B}$ & $0.444 d$ & $0.431 d$ & $0.426 \mathrm{~d}$ & $0.434 \mathrm{C}$ \\
\hline$F_{3}$ & $0.833 \mathrm{bc}$ & $0.892 a b$ & $0.841 \mathrm{ab}$ & $0.855 \mathrm{~A}$ & $0.532 \mathrm{bc}$ & $0.522 \mathrm{c}$ & $0.574 a b$ & 0.543 B \\
\hline$F_{4}$ & $0.908 \mathrm{a}$ & $0.874 a b$ & $0.911 \mathrm{a}$ & $0.898 \mathrm{~A}$ & $0.591 \mathrm{a}$ & $0.597 \mathrm{a}$ & $0.611 \mathrm{a}$ & $0.600 \mathrm{~A}$ \\
\hline Mean & $0.783 \mathrm{~A}$ & $0.810 \mathrm{~A}$ & $0.797 \mathrm{~A}$ & & $0.494 \mathrm{~A}$ & $0.493 \mathrm{~A}$ & $0.506 \mathrm{~A}$ & \\
\hline
\end{tabular}




\section{b- $\mathbf{N}$ content (\%) and carbohydrate content $(\mathrm{mg} / \mathrm{g})$}

Data presented in Table (5) showed that, increasing fertilization rates up to $(15 \mathrm{gm})$ caused significantly increased in $\mathrm{N}$ leaves content $(2.35$ and $2.29 \%$ ) in both seasons, respectively. Bumgarner et al (2008) stated that, fertilization increased nutrient content of Quercus rubra seedlings. Habib (2012) indicated hat, increasing NPK fertilization rate gave the highest content of nitrogen on Caryota mitis seedlings compared with other fertilization rates. On other hand, the three sowing medium were not significant differences on leaves $\mathrm{N}$ content in both seasons of study. For the interaction between sowing medium and fertilization rates, the same data showed that, gradually increased in leaves $\mathrm{N}$ content by increasing fertilization rate without any significant differences between all tested sowing medium. Also, the rate of $15 \mathrm{gm}$ caused significantly increased in carbohy- drate content $(55.4$ and $55.1 \mathrm{mg} / \mathrm{g}$ ) in both seasons, respectively. El-Sallami (1996) on Ficus benjamina reported that, media composed of peat moss + clay or vermiculite and the mixtures of clay + peat + perlite, and clay + sand + vermiculite, increased the content of carbohydrates in the leaves. Moreover, the highest values of carbohydrate content were produced by using the higher fertilization rate $(15 \mathrm{gm})$ at $\mathrm{SM}_{3}(1: 1: 2)$ followed by $\mathrm{SM}_{2}$ (1:2:1). Youssef (2014) reported that, on Beaucarnea recurvate plants grown in composted leaves+ peat moss + vermiculite mixture and received kristalon fertilizer at $6 \mathrm{~g} /$ pot induced the highest values of leaf $\mathrm{N}$ and total carbohydrates contents. The increase in total carbohydrate may be due to the increasing in the concentrations of chlorophyll resulted in an increase in the rate of photosynthesis and a promotion in carbohydrate synthesis and in turn, enhancing of growth (Devlin, 1972).

Table 5. Effect of Sowing medium and fertilization rateson total carbohydrates and $\mathrm{N}$ content of Swietenia macrophylla seedlings during 2015 and 2016 seasons.

\begin{tabular}{|c|c|c|c|c|c|c|c|c|}
\hline \multirow{3}{*}{ Treatments } & \multicolumn{8}{|c|}{2015 Season } \\
\hline & \multicolumn{3}{|c|}{ N content $(\%)$} & \multirow{2}{*}{ Mean } & \multicolumn{3}{|c|}{ Total carbohydrates $(\mathrm{mg} / \mathrm{g})$} & \multirow{2}{*}{ Mean } \\
\hline & S.M.1 & S.M.2 & S.M. .3 & & S.M.1 & S.M.2 & S.M.3 & \\
\hline $\mathbf{F}_{1}$ & $2.10 d$ & $2.11 \mathrm{~cd}$ & $2.09 \mathrm{~d}$ & $2.10 \mathrm{C}$ & $40.7 \mathrm{f}$ & $39.8 \mathrm{f}$ & $40.5 \mathrm{f}$ & $40.3 \mathrm{C}$ \\
\hline $\mathbf{F}_{2}$ & $2.17 c$ & $2.13 \mathrm{~cd}$ & $2.11 \mathrm{~cd}$ & $2.14 \mathrm{C}$ & 42.1 ef & 42.6 ef & $44.3 \mathrm{e}$ & $43.0 \mathrm{C}$ \\
\hline $\mathbf{F}_{3}$ & $2.26 \mathrm{~b}$ & $2.28 \mathrm{~b}$ & $2.31 \mathrm{ab}$ & $2.28 \mathrm{~B}$ & $46.4 \mathrm{de}$ & $47.8 d$ & $50.2 \mathrm{~cd}$ & $48.1 \mathrm{~B}$ \\
\hline$F_{4}$ & $2.33 \mathrm{a}$ & $2.36 \mathrm{a}$ & $2.36 \mathrm{a}$ & $2.35 \mathrm{~A}$ & $52.7 \mathrm{bc}$ & $55.4 \mathrm{ab}$ & $58.3 \mathrm{a}$ & $55.4 \mathrm{~A}$ \\
\hline Mean & $2.21 \mathrm{~A}$ & $2.22 \mathrm{~A}$ & $2.22 \mathrm{~A}$ & & $45.5 \mathrm{~B}$ & 46.4 B & $48.3 \mathrm{~A}$ & \\
\hline \multirow{2}{*}{ Treatmentes } & \multicolumn{8}{|c|}{2016 Season } \\
\hline & S.M.1 & S.M.2 & S.M. .3 & Mean & S.M.1 & S.M.2 & S.M.3 & Mean \\
\hline $\mathbf{F}_{1}$ & $2.02 \mathrm{de}$ & $1.98 \mathrm{e}$ & $2.07 \mathrm{e}$ & $2.02 \mathrm{C}$ & $40.1 \mathrm{e}$ & 40.3 e & $41.2 \mathrm{e}$ & $40.3 \mathrm{C}$ \\
\hline$F_{2}$ & $2.05 d$ & $2.01 \mathrm{e}$ & $2.04 \mathrm{de}$ & $2.03 \mathrm{C}$ & $41.9 \mathrm{e}$ & $42.1 \mathrm{e}$ & $43.2 \mathrm{e}$ & $42.4 \mathrm{C}$ \\
\hline $\mathbf{F}_{3}$ & $2.16 \mathrm{c}$ & $2.19 \mathrm{bc}$ & $2.21 \mathrm{~b}$ & $2.19 \mathrm{~B}$ & $46.1 \mathrm{~d}$ & $47.2 \mathrm{~d}$ & $49.3 \mathrm{~cd}$ & $47.5 \mathrm{~B}$ \\
\hline$F_{4}$ & $2.27 \mathrm{a}$ & $2.31 \mathrm{a}$ & $2.30 \mathrm{a}$ & $2.29 \mathrm{~A}$ & $52.2 \mathrm{bc}$ & $55.5 \mathrm{ab}$ & $57.5 \mathrm{a}$ & $55.1 \mathrm{~A}$ \\
\hline Mean & $2.12 \mathrm{~A}$ & $2.12 \mathrm{~A}$ & $2.16 \mathrm{~A}$ & & $45.1 \mathrm{~B}$ & 46.3 AB & $47.8 \mathrm{~A}$ & \\
\hline
\end{tabular}

\section{C- $\mathrm{P}$ and $\mathrm{K}$ content (\%)}

Data presented in Table (6) showed that, the highest values of $\mathrm{P}(0.50$ and $0.57 \%)$ and $\mathrm{K}(2.51$ and $2.38 \%$ ) in both seasons, respectively produced by using $(15 \mathrm{gm})$ of hydrocomplex in comparison of the other treatments. Also, there were no significant differences among the tested sowing medium on leaves $P$ content in both seasons. On other hand, S.M.2 gave the highest values of leaves $\mathrm{K}$ content $(2.30$ and $2.23 \%$ ) in the two study seasons, respectively. Using higher fertilization rate (15 g/plant) in all sowing medium gave the highest values of leaves $P$ content in the first and second season as compared to the other fertilization rates. Also, application the rate of (15 g/plant) fertilization with sowing medium S.M.2 (1:1:2) produced the highest values of leaves $\mathrm{K}$ content (2.64 and $2.47 \%$ ) in comparison the other treatments in both seasons, respectively. Saleh (2000) on Ficus benjamina indicated that, peat moss + sand + clay mixture increased the contents of $\mathrm{P}$ and $\mathrm{K}$. 

Mahogany (Sweitinia macrophylla) seedlings

Table 6. Effect of Sowing medium and fertilization rates on $\mathrm{P}$ and $\mathrm{K}$ content of Swietenia macrophylla seedlings during 2015 and 2016 seasons.

\begin{tabular}{|c|c|c|c|c|c|c|c|c|}
\hline \multirow{3}{*}{ Treatments } & \multicolumn{8}{|c|}{2015 Season } \\
\hline & \multicolumn{3}{|c|}{ P content (\%) } & \multirow{2}{*}{ Mean } & \multicolumn{3}{|c|}{ K content (\%) } & \multirow{2}{*}{ Mean } \\
\hline & S.M.1 & S.M.2 & S.M.3 & & S.M.1 & S.M.2 & S.M.3 & \\
\hline$F_{1}$ & $0.30 \mathrm{e}$ & $0.30 \mathrm{e}$ & $0.33 \mathrm{de}$ & $0.31 \mathrm{C}$ & $1.91 \mathrm{e}$ & 1.85 e & $2.02 \mathrm{de}$ & $1.93 \mathrm{C}$ \\
\hline$F_{2}$ & $0.36 \mathrm{~cd}$ & $0.36 \mathrm{bc}$ & $0.41 b c$ & $0.38 \mathrm{~B}$ & $2.06 \mathrm{de}$ & $2.08 \mathrm{de}$ & $2.19 \mathrm{~cd}$ & $2.11 \mathrm{~B}$ \\
\hline$F_{3}$ & $0.42 b$ & $0.42 \mathrm{~b}$ & $0.43 \mathrm{~b}$ & $0.42 \mathrm{~B}$ & $2.20 \mathrm{~cd}$ & $2.24 \mathrm{~cd}$ & $2.35 b c$ & $2.26 \mathrm{~B}$ \\
\hline$F_{4}$ & $0.51 \mathrm{a}$ & $0.50 \mathrm{a}$ & $0.50 \mathrm{a}$ & $0.50 \mathrm{~A}$ & $2.39 \mathrm{bc}$ & $2.51 \mathrm{ab}$ & $2.64 \mathrm{a}$ & $2.51 \mathrm{~A}$ \\
\hline Mean & $0.40 \mathrm{~A}$ & $0.41 \mathrm{~A}$ & $0.42 \mathrm{~A}$ & & $2.14 \mathrm{~B}$ & $2.17 \mathrm{~B}$ & $2.30 \mathrm{~A}$ & \\
\hline \multirow{2}{*}{ Treatmentes } & \multicolumn{8}{|c|}{2016 Season } \\
\hline & S.M.1 & S.M.2 & S.M.3 & Mean & S.M.1 & S.M.2 & S.M.3 & Mean \\
\hline$F_{1}$ & $0.40 \mathrm{~d}$ & $0.36 \mathrm{~d}$ & $0.35 d$ & $0.37 \mathrm{C}$ & $1.90 \mathrm{~d}$ & $1.93 \mathrm{~d}$ & $2.00 \mathrm{~d}$ & $1.94 \mathrm{~B}$ \\
\hline$F_{2}$ & $0.47 \mathrm{c}$ & $0.45 c$ & $0.48 \mathrm{bc}$ & $0.46 \mathrm{~B}$ & $2.07 \mathrm{~cd}$ & $2.00 \mathrm{~d}$ & $2.04 \mathrm{~d}$ & $2.04 \mathrm{~B}$ \\
\hline$F_{3}$ & $0.52 a b$ & $0.53 a b$ & $0.53 a b$ & $0.53 \mathrm{~A}$ & $2.24 \mathrm{bc}$ & $2.25 \mathrm{bc}$ & $2.41 a b$ & $2.30 \mathrm{~A}$ \\
\hline$F_{4}$ & $0.57 \mathrm{a}$ & $0.57 \mathrm{a}$ & $0.56 \mathrm{a}$ & $0.57 \mathrm{~A}$ & $2.29 a b$ & $2.39 a b$ & $2.47 \mathrm{a}$ & $2.38 \mathrm{~A}$ \\
\hline Mean & $0.49 \mathrm{~A}$ & $0.47 \mathrm{~A}$ & $0.48 \mathrm{~A}$ & & $2.13 \mathrm{~B}$ & $2.14 \mathrm{~B}$ & $2.23 \mathrm{~A}$ & \\
\hline
\end{tabular}

\section{RECOMMENDATION}

Application of fertilization rate at $15 \mathrm{~g} /$ plant with sowing medium which contain the high ratio of compost $(1: 1: 2)$ produced the highest characteristics of mahogany seedlings followed by which contain the high ratio of peat moss $(1: 2: 1)$.

\section{REFERENCES}

Agbo, C.U. and Omaliko, C.M. 2006. Initiation and growth of shoots of Gongronema latifolia (Benth) stem cuttings in different rooting media. Afr. J. Biotech, 5(5), 425- 428.

Al-Menaie, H.S., Al-Ragom, O., Al-Shatti A., Mathew, M. and Suresh, N.A. 2012. Effect of Fertilizer Concentration on the Growth Performance of Cassia nodosa Buch.-Ham. Ex Roxb. And Cassia fistula L. Seedlings under Greenhouse Conditions of Kuwait. International Research Journal of Plant Science, 3(2), 19-22.

Bhardwaj, R.L. 2014. Effect on seed germination and seedling growth of Papaya cV red lady. Afr. J. Plant Sci., 8(4), 178-184.

Bumgarner, M.L., Salifu, K.F. and Jacobs, D.F. 2008. Sub irrigation of Quercus rubra seedlings: Nursery stock quality, media chemistry, and early field performance. Hort Science, 43(7), 2179-2185.
Chapman, H.D. and Pratt, P.F. 1961. Methods of Analysis for soils, plant and water. Div.of Agric. Sci. Univ. of Calif, 309 P.

Cottenie, A., Verloo, M., Kiekens, L., Velghe, G. and Camerlynck, R. 1982. Chemical Analysis of Plant and Soil Laboratory of Anolytical and Agrochemistry, State Univ. Ghent. Belgium, pp. 100-129.

Ching, L.L., Edwards, S. and Nadia E. Scialabba, 2011. Climate Change and Food Systems Resilience In Sub-Saharan Africa. Food And Agriculture Organization of The United Nations (FAO) Rome, 436 P.

Devlin, R.M. 1972. Plant Physiology, $3^{\text {rd }}$ Ed. Van Nostr and Company, New York, USA, 1001 P.

Duncan, D.B. 1955. Multiple Range and Multiple F Tests. Biometrics 11, 1-42.

EL-Quasni, F.E.M., Mazhar, A.M., Sakr, S.S., ELKhateeb, M.A. and Abd EL-Magied, H.M. 2014. Effect of some Growing Media on Growth and chemical constituents of Magnolia seedlings. (Magnolia grandiflora). Middle East Journal of Agriculture Research, 3(4), 869875.

El-Kady, A. F.Y. and Suloma, A. 2013. Towards Wastewater-Aquaculture-Agriculture Integration in Arid and Semi-Arid Regions: Utilization of Aquaculture Effluents in the Irrigation of Khaya and Mahogany Seedlings. Journal of Horticul- 
tural Science \& Ornamental Plants 5(3), 227237.

EL-Kateeb, M.A., EL-Maadawy, E.E. and ELAtter, A.A. 2006. Effect of growing media on growth and chemical composition of Ficus alli plants. Annals of Agriculture Science Moshtohor, 46(2), 1987-1998.

EL-Sallami, I.H. 1996. Response of Ficus benjamina L. to different potting media and doses of nutrient solution. Assiut J. of Agric. Sci., 27(3), 61-76.

Habib, A.M. 2012. Effect of NPK and Growing Media on Growth and Chemical Composition of Fishtail Palm (Caryota mitis Lour). Life Science Journal 9(4), 3169-3168.

Hamdan, A.A. 2012. Effect of Sowing Method and NPK Fertilizer Application on Growth of Seedlings of Swietenia macrophylla King at nursery. J. Pemuliaan Tanaman Hutan, 6(1), 1- 10.

Herbert, D., Phipps, P.J. and Strange, R.E. 1971. Chemical analysis of microbial cells. In: "Methods in Microbiology". pp. 209-344. London Academic Press.

Jayasinghe, S. and Ranasinghe, D.M.S.H.K. 2009. Investigation into the optimal fertilizer regime of Swietenia macrophylla (Mahogany). Proceedings of the $14^{\text {th }}$ International Forestry and Environment Symposium, 14(1), 915.

Mayhew, J. E. and Newton, A.C. 1998. The Silviculture of Mahogany. CABI Publishing, Oxford. UK, 226 P.

Saleh, S.I. 2000. Effect of different planting media on the growth and chemical composition of $\mathrm{Fi}$ cus benjamina "Star Light" plants grown under two locations "outdoor and plastic house" conditions. Egyptian Journal Hort,, 27(4), 543568.

Sardoei, A.S. and Rahbarian, P. 2014. Effect of different media on growth indexes of ornamen- tal plants under system mist. European Journal of Experimental Biology, 4(2), 361-365.

Saric, M., Kostrori, R., Cupina, T. and Geric, I. 1967. Chlorophyll determination univ. U. Noven Sadu Prakitikum is kiziologize Bilijaka Beogard, Haucana, Anjiga,215 P.

Snedecor, G.W. and Cochran, W.G. 1982. Statical Methods. lowa State Univ. Press, USA, 507 P.

Snell, F.D. and Snell, C.T. 1949. Colorimetric methods analysis including some turbidimetic and nephelometric methods. Vol.2. Inorganic. Van Nostrand, Toronto, Canada.

Ugur, S., Eratan E. and Eratan, B. 2010. Growth Substrates and Fig nursery tree production. Sci. Agric., 67(6), 633-638.

Vidyasagaran, K. and Kumar, V. 2017. Evaluation of municipal garbage as a component of potting media for economically important timber species seedlings for afforestation in tropics. Journal of Environmental Biology, 38, 7-14.

Vivekanandan, A.S., Gunasena, H.P.M. and Sivanayagam, T. 1972. A statistical evaluation of the accuracy of three techniques used in the estimation of leaf area of crop plants. Indian $\mathbf{J}$. Agric. Sci., 42(9), 857-860.

Watfa, R.A. 2009. Effect of soil media, nutrition and mycorrhiza fungi on growth and chemical composition of carob and Aleppo pine seedlings. M.Sc. Thesis, Fac. Agri. Cairo Univ., Egypt, 171p.

Zhang, F., Niu, J., Zhang, W., Chen, X., Li, C., Yuan, L. and Xie, J. 2010. Potassium nutrition of crops under varied regimes of nitrogen supply. Plant and Soil, 335, 21-34.

Youssef, A.S.M. 2014. Effect of different growing media and chemical fertilization on growth and chemical composition of ponytail palm (Beaucarnea recurvata) plant. Annals of Agric. Sci. Moshtohor, 52(1), 27-38. 